\title{
The Relationship of Good University Governance and Student Satisfaction
}

\author{
Muhsin $^{1}$, S Martono ${ }^{1}$, Ahmad Nurkhin ${ }^{1}$, Hengky Pramusinto ${ }^{1}$, Nely Afsari ${ }^{1} \&$ Ahmad Fadhly Arham ${ }^{2}$ \\ ${ }^{1}$ Faculty of Economics, Universitas Negeri Semarang, Semarang, Central Java, Indonesia \\ ${ }^{2}$ Faculty of Management and Business, Universiti Teknologi Mara, Cawangan, Melaka, Malaysia \\ Correspondence: Muhsin, Faculty of Economics, Universitas Negeri Semarang, Semarang, Central Java, Indonesia. \\ E-mail: muhsin@mail.unnes.ac.id
}

Received: September 6, 2019

Accepted: October 15, 2019

Online Published: October 23, 2019

doi:10.5430/ijhe.v9n1p1

URL: https://doi.org/10.5430/ijhe.v9n1p1

\begin{abstract}
The purpose of this paper is to examine the relationship of good university governance, teaching quality of lecturers and student satisfaction. It also aims to examine the effect of learning facilities on good university governance and student satisfaction. 361 students of the Faculty of Economics, Semarang State University, were involved in this study using proportionate random sampling. Then, to gather the data, a questionnaire was distributed, and the data were analyzed by applying SEM-PLS. The results showed that good university governance, teaching quality of lecturers, and learning facilities had a positive and significant effect on student satisfaction. The teaching quality of lecturers is proven to be influenced by good university governance. In addition, learning facilities also have a significant effect on good university governance.
\end{abstract}

Keywords: student satisfaction, teaching quality of lecturers, good university governance, learning facilities

\section{Introduction}

Currently, providing better services and managing student satisfaction are among the top priorities for universities. In fact, many demonstrations happened due to the lack of service quality in higher education, as well as student satisfaction. Kardoyo \& Nurkhin (2016) stated the implementation of education should provide quality services for the customers. Thus, at the university, service quality reflects the quality of education management.

Student satisfaction has become an important concept in higher education because students are paying higher tuition fees and increasingly seeing themselves as customers and because satisfaction is commonly used as an indicator of quality by quality assurance agencies and the compilers of rankings and league tables (Xiao \& Wilkins, 2015). Student satisfaction becomes important in order to achieve the university's vision and mission. Student satisfaction reflects the emotional condition of students in feeling the services provided during studies on campus. Ali, Zhou, Hussain, Nair, \& Ragavan (2016) contended that students are the main customers in college. While other experts refer to students as primary customers and partners. Student satisfaction is a short-time attitude, as a result of experience gained from educational services that have been established.

Student satisfaction level has become a major focus of researchers in the competitive learning environment owing to its strong impact on the success of educational institutes and prospective student registration since the past few decades (Weerasinghe \& Fernando, 2018a). Many researchers have established relationships between students satisfaction with the service quality and loyalty (Ali et al., 2016; Annamdevula \& Bellamkonda, 2016; Fernandes, Ross, \& Meraj, 2013). Their findings can be summarized as sstudent's satisfaction is highly determined by the service quality which in turn will affect students' loyalty. However, some did not find direct effect of service quality with student satisfaction (Osman \& Saputra, 2019).

In addition to service quality factors, there are several factors that influence student satisfaction including the quality of lecturers and learning facilities. Lecturers' ability to teach is an important factor in influencing student satisfaction. Qualified lecturers will be able to create a fun and meaningful learning process. Students can easily involve in the learning process and eventually will gain important experience to continue to improve understanding and other competencies. Fernandes, Ross, \& Meraj (2013) found that the quality of lecturers became the main reason of student satisfaction. Osman \& Saputra (2019) confirmed that the teaching method used by lecturers can be seen as an 
indicator of program quality in which it has a significant effect on student satisfaction. Teaching staff with a higher level of commitment to the student learning experience proved to have a significant influence on student satisfaction (Poon \& Brownlow, 2015). However, there are researchers who did not find a significant effect of the quality and teaching model of lecturers on student satisfaction (Carter \& Yeo, 2016; Martirosyan, 2015).

Student support facilities, internet technology and library services in particular, play an important role in students' success in postsecondary education (Martirosyan, 2015). The availability of facilities and their quality are confirmed to affect the students' satisfaction. Students can involve in the learning process well once the facilities are complete and have good quality. Martirosyan (2015) and Weerasinghe \& Fernando (2018) found the significant relationship between the quality of higher education on students satisfaction. Then, Weerasinghe \& Fernando (2018b) found the effect of facilities in higher education towards students satisfaction. The facilities include lecturer's room, facilities at the library, computer, accommodation, facilities for employees, and entertainment. It was only computer facility which was not proven to have significant effect on student satisfaction. Other study by Carter \& Yeo (2016) mentioned that there was not significant effect of facilities on students satisfaction measured by student persistence.

Within the area of the determinants of student satisfaction, good university governance (GUG) is an infant variable. Derived from the concept of good governance, GUG is very important for universities to create a management model that is more transparent, accountable, and compliant with applicable regulations. GUG can improve the quality of university management. As known that the quality of university management is crucial in encouraging academic quality, so that the colleges should be managed professionally. Universities must be accountable to stakeholders (internal and external). This means public accountability is a must. This is expected to enforce the principles of good university governance. Wahyudin, Nurkhin, \& Kiswanto (2017) argue that the implementation of good governance in higher education has been massively encouraged to be practiced. The concept of good governance previously applied to companies is considered to resolve problems or as a preventive effort in improving the quality of university financial management. The concept is in the form of Good University Governance (GUG).

There are a few studies that attempted to link GUG with student satisfaction or the quality of lecturers on teaching. Aprilia (2017) measured GUG with five (5) principles (transparence, accountability, responsibility, independence, fairness) and found a positive and significant influence on student authority. GUG implementation will create a more transparent and accountable management of higher education institutions. And students will be more satisfied and believe in higher education management.

The purpose of this study is to examine the effect of good university governance on the teaching quality of lecturers and student satisfaction. The study also examines the effect of learning facilities on the teaching of lecturer and satisfaction. This study will examine the effect of good university governance on the teaching quality of lecturers and student satisfaction. The GUG variable is a new variable in the student satisfaction research model. This study also examines the effect of learning facilities on the teaching quality of lecturers and student satisfaction. It is expected that the outcome of this study will improve on the deliverance of student satisfaction at the universities.

\section{Literature Review}

\subsection{The Equity Theory}

The equity theory explained the balance between the effort an employee puts into their work (input), and the result they get in return (output) (Adams \& Freedman, 1976). In a higher education context, results of a process are pertinent to various outcomes such as service quality, program quality, placement, image of the institution, competent graduate, employability rate, quality research outcomes, quality academic materials, industrial link and international recognition. These results of a process are not restricted to particular factors or to a specific situation. They are diverse in nature therefore applicability of the Equity Theory is universal in explaining customer behavior and satisfaction (Osman \& Saputra, 2019).

\subsection{The Concept of Student Satisfaction}

Satisfaction is the feeling of one's happiness or disappointment by comparing the perceived performance of the product (or result) to their expectations (Kotler \& Keller, 2008). Satisfaction reflects a person's judgment about the product's perceived performance (or results) related to expectations. If the performance does not meet the expectations, customers are not satisfied and disappointed. If product performance met their expectations, the customer is satisfied. If product performance exceeds expectations, customers feel satisfied and happy. Tajuddin, Nimran, Astuti, \& Kertahadi (2016) argued that user satisfaction emphasizes user perceptions. User satisfaction is used to measure the gap that may occur between expectations and the reality of the quality of the system received by the user. 
Almana, Sudarmanto, \& Wekke (2018) stated that measurement of service quality and customer satisfaction can be seen from two perspectives, namely expectation theory and perception theory. In expectation theory, customer satisfaction is measured by the expected performance of goods or services compared to actual performance. Meanwhile, in perception theory, customer satisfaction is measured based on customer perceptions of the performance of goods or services perceived after buying and consuming goods or services. Besides, Tjiptono \& Chandra (2015) identified methods for measuring customer satisfaction, namely: complaint and suggestion system, customer satisfaction surveys, ghost shopping, and lost customers analysis.

Factors that affect student learning satisfaction are important to understand to improve the teaching performance of lecturers. There are several factors that influence learning satisfaction, namely attitudes, knowledge, methods and facilities, motivation, learning atmosphere, and learning outcomes (Listyaningrum, Handoyo, \& Murtinugraha, 2016). While according to Tjiptono (2002), the factors related to customer satisfaction are: (1) product quality and consumer service have certain needs and expectations, (2) sales activities consist of message variables, attitudes, and intermediaries, (3) service and (4) company value variables (official values and informal values).

\subsection{The Concept of Good University Governance}

Implementation of Good University Governance refers to the implementation of Good Governance based on Agency theory (Wahyudin et al., 2017). Implementation of Good Governance arises as a form of effort to minimize differences in interests between the owner (principal) and management (agent) that was first developed by Jensen \& Meckling (1976). Agency theory is considered as a theoretical approach that is most suitable to underlie the GUG concept in this study. Management of higher education institutions (agents) will carry out their duties in accordance with contracts or government regulations and university statutes if supervision activities are carried out properly.

Jensen \& Meckling (1976) introduced the idea that a company is a nexus of agreement which implies that within a company there is a set of reciprocal contracts that facilitate between company owners, employees, suppliers and other stakeholders related to the company. A good agreement between investors and managers is an agreement which is able to explain the specifications of what managers must do in managing investors' funds, and specifications about the distribution of returns between managers and investors.

The GUG concept is also based on stakeholder theory developed by Freeman, Wicks, \& Parmar (2004) stating that stakeholder theory is a group of people or individuals identified as influencing company activities or can be influenced by company activities. Ghozali \& Chariri (2007) confirmed stakeholder theory considers companies as not entities that only operate for their own sake, but also, they should be able to provide benefits to their stakeholders. Thus, the existence of a company is strongly influenced by the support provided by the stakeholders of the company. Wahyudin et al. (2017) argued that like corporations, universities also need to think about strategic stakeholders or public who need special management.

In 2005, a good university governance is a similar concept emerged for universities. Both concepts of good corporate governance and good university governance are actually derivatives of the concept of more general governance, namely good governance. In simple terms good university governance can be seen as the application of principles in the concept of good governance in systems and processes of governance in higher education institutions (Martini, Sari, \& Wardhani, 2015).

Good University Governance is a concept that arises because of the awareness that the implementation of higher education and higher education institutions cannot be equated with the administration of a country or corporation. Universities have their own values to maintain. In the implementation. Thus, a measurement can be determined to see whether a university has implemented Good University Governance to keep responding the dynamics happening in the university without neglecting the values and the mandate from society, the nation and the surrounding country (Wahab \& Rahayu, 2013).

Wahyudin et al. (2017) measured Good University Governance based on the principles contained in GCG, namely information disclosure (transparency), accountability, responsibility/responsiveness, independence, and fairness. Meanwhile, Wahab \& Rahayu (2013) used other indicators to measure namely participation, rule of law, transparency, responsiveness, consensus oriented, equity \& inclusiveness, effectiveness \& efficiency, and accountability.

Martini et al. (2015) used indicators of governance structure, autonomy, accountability, leadership, and transparency to measure good university governance. Meanwhile, the Directorate of Institutions and Cooperation of the Directorate General of Higher Education of the Ministry of Education and Culture stated the principles of corporate governance in higher education or often referred to as good university governance, namely: transparency, 
accountability, responsibility, independence, fairness, guarantee of quality and relevance, effectiveness and efficiency, and non-profit.

\subsection{Research Framework and Hypotheses Development}

The success of both profit and non-profit organizations or institutions, government or non-government, is influenced by many factors. One important factor is customer satisfaction (Motefakker, 2016). The main customers in college are students. Student satisfaction is very important to give more attention. Many factors influence student satisfaction. This research is limited to the factors of lecturers, facilities, and new factors, namely good university governance. GUG is an important factor for creating quality teaching and student satisfaction.

Lecturers are an important factor in influencing student satisfaction. The ability of lecturers in teaching, overall lecturer performance will cause the lecture process to become more qualified. Then, ultimately, student satisfaction will increase. Many researchers have proven the significant influence of teaching quality on student satisfaction. The quality of teaching lecturers has a positive and significant effect on student satisfaction (Sabihaini \& Satoto, 2016). Isnaini, Wardani, \& Noviani (2015) also found a significant effect of lecturer competence on student satisfaction. Lecturer professionalism is the dominant factor that influences student satisfaction (Rahmawati, 2013). Lecturer performance has a significant effect on student satisfaction (Putri, 2018). Lecturer expertise is the most influencing factor for student satisfaction (Butt \& Rehman, 2010).

Factors that influence student satisfaction are facilities-its quantity and quality. The better quality of facilities will affect student satisfaction. Learning facilities have a positive and significant effect on student satisfaction (Butt \& Rehman, 2010; Isnaini et al., 2015; Khosravi, Poushaneh, Roozegar, \& Sohrabifard, 2013; Sabihaini \& Satoto, 2016). Negricea, Edu, \& Avram (2014) used variable tangible elements to measure the modernity of equipment, campus facilities, the existence of seminar rooms and lecturers, equipment owned by the campus. He found a positive and significant influence on student satisfaction. And the effect is greater than the other two variables (reliability and the compliance with university's value).

Good university governance (GUG) is an effort to create a better university management. Muktiyanto (2016) argued GUG has a positive effect on university performance. Thus, GUG can improve the performance of lecturers- their teaching ability and student satisfaction. GUG demands transparency and accountability. Lecturers should show good performance in lecture activities in the classroom as well as in research and service. Lecturer performance will be well known by students. Student satisfaction will increase if the lecturer is able to show quality performance. There are not many researchers who try to link the implementation of GUG to the quality of teaching lecturers and student satisfaction. Aprilia (2017) found a positive and significant effect of GUG on student satisfaction.

The research framework is as in figure 1.

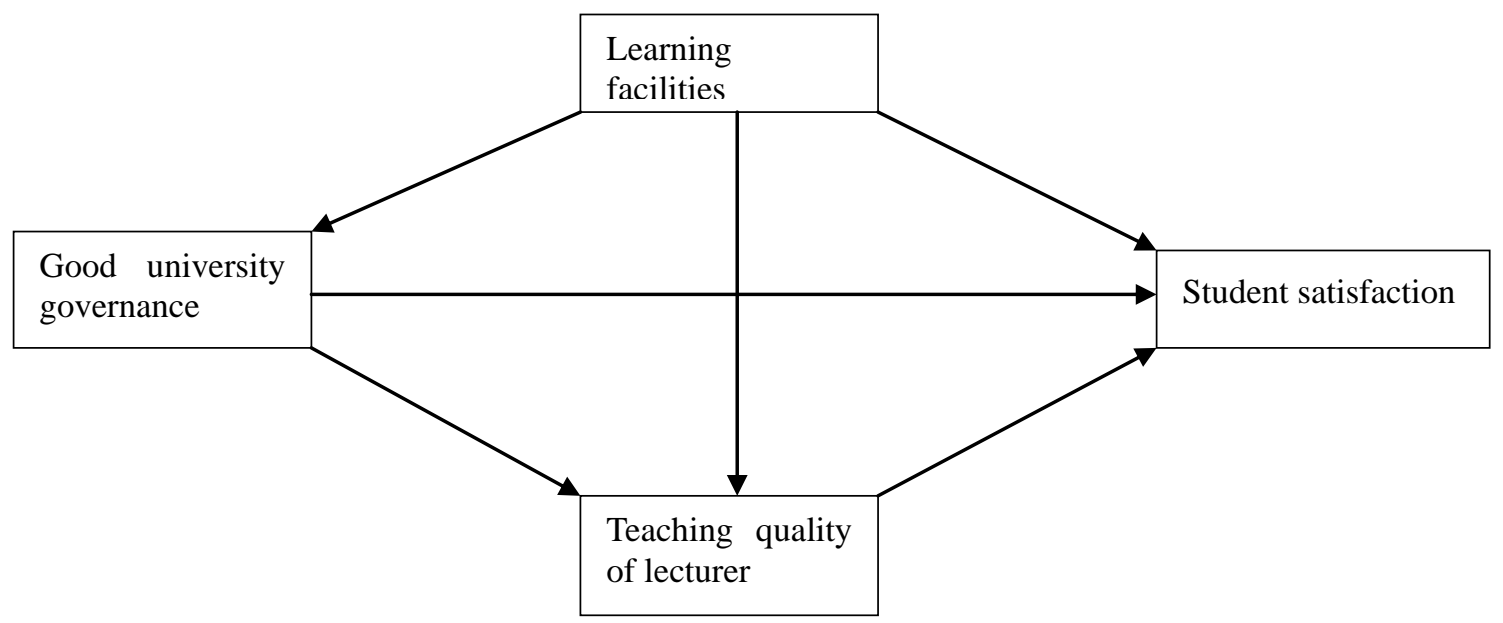

Figure 1. Conceptual Framework

The research hypotheses are as follows;

H1 good university governance has a positive and significant effect on student satisfaction

$\mathrm{H} 2$ good university governance has a positive and significant effect on teaching quality of lecturers 
H3 teaching quality of lecturer has a positive and significant effect on student satisfaction

H4 learning facilities have a positive and significant effect on student satisfaction

H5 learning facilities have a positive and significant effect on teaching quality of lecturers

H6 learning facilities have a positive and significant effect on good university governance

H7 teaching quality of lecturers are able to mediate the relationship between good university governance towards student satisfaction

H8 teaching quality of lecturers able to mediate the relationship between learning facilities to student satisfaction

\section{Methods}

The population in this study was active students of the Faculty of Economics, Semarang State University in the 2018/2019 academic year, as many as 3,633 students. Consisting of students from the Economics Education study program, Accounting Education, Office Administration Education, Accounting, Management, and Development Economics. The sample size was determined using the Slovin formula at an error rate of 5\% and obtained as many as 361 respondents. The sampling method used was proportionate random sampling. The distribution of research samples is in table 1 .

Table 1. Research Sample Distribution

\begin{tabular}{ccccc}
\hline No. & Major & $\begin{array}{c}\text { Total } \\
\text { Students }\end{array}$ & Percentage & $\begin{array}{c}\text { Number of } \\
\text { samples }\end{array}$ \\
\hline 1. & Accounting Education & 546 & $15 \%$ & 54 \\
2. & Cooperative Education & 410 & $11 \%$ & 40 \\
3. & Office Administration Education & 427 & $12 \%$ & 43 \\
4. & Accounting & 828 & $23 \%$ & 83 \\
5. & Management & 889 & $24 \%$ & 87 \\
6. & Development Economics & 533 & $15 \%$ & 54 \\
\hline & Total & 3.633 & $100 \%$ & 361 \\
\hline
\end{tabular}

The research variables included student satisfaction, good university governance, learning facilities and learning quality of lecturer. The operational definition is in table 2 . 
Table 2. Operational Variable Definition

\begin{tabular}{|c|c|c|}
\hline No. & Variable & Operational Definition \\
\hline 1. & $\begin{array}{c}\text { Student } \\
\text { Satisfaction }\end{array}$ & $\begin{array}{l}\text { Feeling happy or disappointed of someone } \\
\text { because comparing the perceived performance of } \\
\text { the product (or result) to their expectations. }\end{array}$ \\
\hline 2. & $\begin{array}{c}\text { Good } \\
\text { University } \\
\text { Governance }\end{array}$ & $\begin{array}{l}\text { The extent in which higher education institutions } \\
\text { are able to respond to the dynamics that occur in } \\
\text { the implementation of education without } \\
\text { betraying the noble values and mandate that they } \\
\text { carry out from the community, the nation and the } \\
\text { country. }\end{array}$ \\
\hline 3. & $\begin{array}{l}\text { Teaching } \\
\text { Quality of } \\
\text { Lecturer }\end{array}$ & $\begin{array}{l}\text { The ability of a professional educator and } \\
\text { scientist in delivering knowledge or giving } \\
\text { lessons to students. }\end{array}$ \\
\hline $\begin{array}{l}4 \\
.\end{array}$ & $\begin{array}{l}\text { Learning } \\
\text { Facilities }\end{array}$ & $\begin{array}{l}\text { Educational facilities are all facilities (equipment, } \\
\text { materials, and furniture) that are directly used in } \\
\text { the teaching and learning process, both tangible or } \\
\text { intangible so that the achievement of educational } \\
\text { goals can run smoothly, regularly, effectively, and } \\
\text { efficiently. Educational infrastructure is a facility } \\
\text { that indirectly supports the course of the } \\
\text { education or teaching process. }\end{array}$ \\
\hline
\end{tabular}

Indicator

a) The fulfillment of Expectation

b) Interest to revisit,

c) Availability of Recommendation.
a) Transparency
b) Accountability
c) Responsibility
d) Independence
e) Justice

f) Quality assurance and relevance

g) Effectiveness and efficiency

h) Non-profit

a) Knowledge background

b) Lecturer's decision

c) Classroom atmosphere

d) Quality of learning process and its

$$
\text { context }
$$

a) Quality of building and classroom

b) Quality of classroom's chairs

c) Quality of board in the classroom

d) Quality of LCD projector

e) wi-fi in the classroom

f) Quality of lighting in the classroom

g) Comfort in the classroom

h) Adequate numbers of books in the

$$
\text { library }
$$

i) Comfort in the library

j) Quality and cleanliness of the toilet

k) Adequacy of space for worship

1) Adequacy of parking facilities

m) Adequacy of canteen facilities

The primary data were collected through the result of questionnaire distribution. The questionnaire used is a closed questionnaire that contains a statement using alternative answers so that respondents can simply choose the alternative answers provided. The scale of the data used is a 5-point Likert scale. The Likert scale has gradations from very positive to very negative. The data analysis method used is SEM analysis. SEM analysis is considered to provide the ability to conduct path analysis with latent variables. SEM analysis in this study used the SEM-PLS method using the WarpPLS 6.0 application.

\section{Results}

Table 3 presents descriptive statistics of the research variables. It shows student satisfaction variables, teaching quality of lecturers, and good university governance are included in the high category. While learning facilities are in 
the medium category. Students consider the service received to be satisfying. Students also consider the quality of teaching of the lecturers to be very positive. That is, lecturers can teach well. While the available learning facilities are considered normal.

Table 3. Descriptive Statistics of Research Variables

\begin{tabular}{ccccc}
\hline Research Variable & Minimum & Maximum & Mean & Std. Deviation \\
\hline Student satisfaction & 17.00 & 45.00 & 33.7950 & 5.74138 \\
Good university governance & 26.00 & 80.00 & 58.0609 & 9.83682 \\
Teaching quality of lecturer & 22.00 & 60.00 & 46.6066 & 7.10754 \\
Learning facilities & 20.00 & 65.00 & 44.1828 & 7.87858
\end{tabular}

The results of data were then analyzed using SEM with WarpPLS software. The model test results used the Average path coefficient (APC) criteria, Average adjusted R-squared (AARS), Average R-squared (ARS), VIF (AVIF) Average block, and Average full collinearity VIF (AFVIF). The model test results showed APC $=0.372, \mathrm{P}<0.001$; ARS $=0.483, \mathrm{P}<0.001$; and AARS $=0.480, \mathrm{P}<0.001$. The $\mathrm{P}$ values of APC, ARS, and AARS are less than 0.001 which means that the model has been fit (fulfilling the requirements) so that hypothesis testing can be continued. The results of the next model test showed AVIF $=1.942$, acceptable if $<=5$, ideal $<=3.3$; AFVIF $=2.196$, acceptable if $<=5$, ideal $<=3.3$. AVIF and AFVIF values also meet the ideal limit so that the model can be declared fit (fulfilling the requirements).

Figure 2 showed the results of hypothesis testing. The P (probability) value of GUG (Good University Governance), LF (Learning Facilities), and TQL (Teaching Quality of Lecturer) showed less than or equal to 0.005 . This means there were three variables having a positive and significant effect on SS (Student Satisfaction), with path coefficients of $0.48 ; 0.09$ and 0.23 . GUG has a greater path coefficient showing that GUG was the main predictor in this research model.

GUG also proved to have a positive and significant effect on TQL. This is indicated by a $\mathrm{P}$ value of less than 0.01 with a path coefficient of 0.40 . The $\mathrm{P}$ value from LF to TQL is $<0.01$ with a path coefficient of 0.8 . This means LF has a positive and significant influence on TQL. The results of the study also showed TQL proved to be the mediator of the relationship between GUG and LF to the SS. GUG and LF can influence SS significantly both directly and indirectly (through TQL). The results also showed that LF was able to influence GUG positively and significantly (P value $<0.01$ with path coefficient $=0.66$ ).

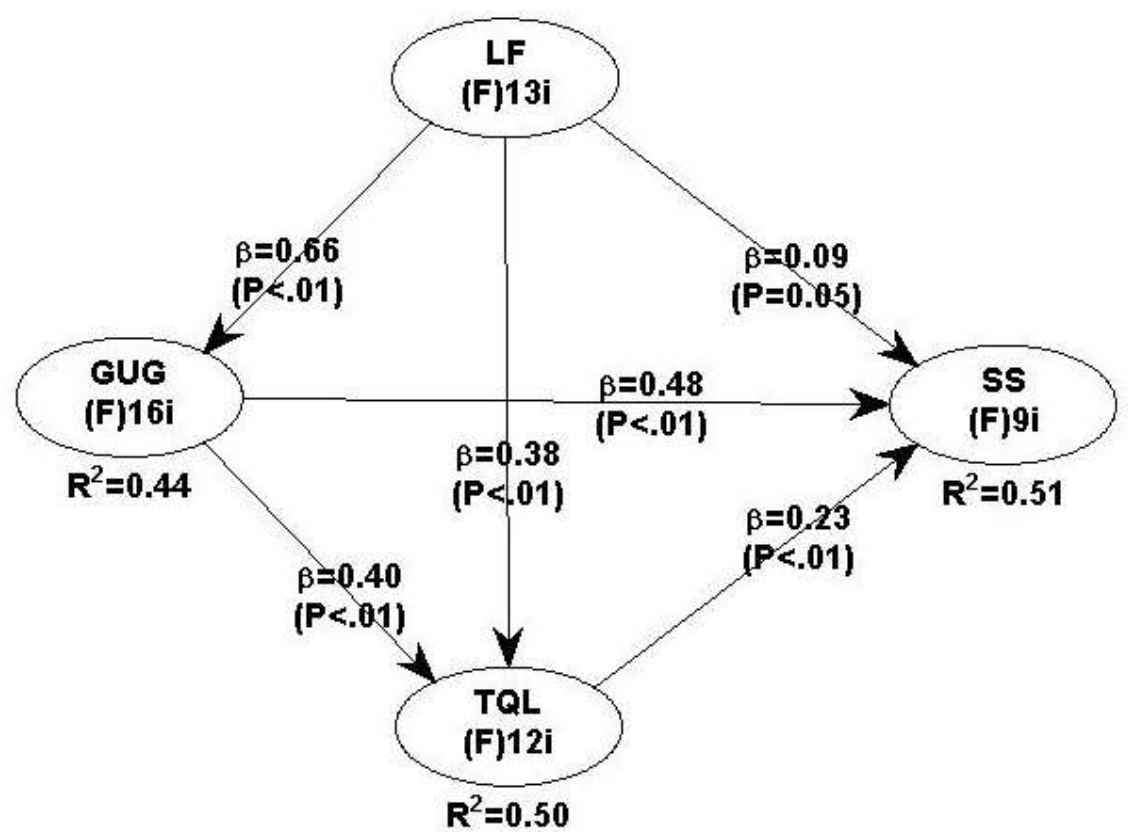

Figure 2. Path Diagram 


\section{Discussion}

Good university governance proved to have a significant effect on teaching quality of lecturers and student satisfaction. This means the better the governance of higher education, the better the quality of teaching lecturers and student satisfaction. GUG will have an impact on improving the quality of teaching lecturers. The GUG principle requires openness, responsibility, excellent service, fairness and more. Lecturers will strive to improve the quality of their teaching because the demand from universities. The GUG principle will also encourage student satisfaction to be better. Students will obtain information disclosure, management accountability, best service, treatment justice, independence, and other benefits. College managers will try to carry out their mandates and responsibilities based on the GUG principle.

As stated by Muktiyanto (2016), GUG has a positive and significant effect on the performance of universities. One indicator of college performance is increasing student satisfaction. Wahyudin, Nurkhin, \& Kiswanto (2017) found a significant effect of GUG on organizational culture and college financial management performance. Aprilia (2017) has successfully proven that GUG has a positive and significant effect on student satisfaction.

The results of the study also showed student satisfaction is influenced by teaching quality of lecturers and learning facilities. This is reasonable if students can enjoy adequate learning facilities or even high quality so they will get satisfied. Conversely, if students get poor learning facilities, students will get dissatisfied and do "protest" to the college leaders. Even when the number of students is too large will also affect the teaching and learning experience which in turn will influence student satisfaction (Beecham, 2009). The ability of lecturers in teaching will also affect student satisfaction. Students have high expectation on the quality of teaching lecturers so that they can improve their learning result Students will be more enthusiastic in lectures and completion of studies. The results of the study supported the results of previous studies which found a positive and significant effect on student satisfaction (Butt \& Rehman, 2010; Carter \& Yeo, 2016; Fernandes et al., 2013; Isnaini et al., 2015; Martirosyan, 2015; Osman \& Saputra, 2019; Putri, 2018; Rahmawati, 2013; Sabihaini \& Satoto, 2016).

The existence and quality of learning facilities also proved to have a positive and significant effect on the quality of teaching lecturers. The better the quality of lecture facilities, the lecturer will create interesting and meaningful learning. Lecturers will be more optimum in creating better learning process if the facilities in the classroom and laboratory are of high quality and adequate. The speed of the internet network, for example, will greatly influence lecturers in finding the latest learning resources and in a faster time. Interactive lectures will be able to be created in class if the internet network through wi-fi runs smoothly. The results of this study supported the findings of previous researchers who found that facilities had a positive and significant effect on student satisfaction (Butt \& Rehman, 2010; Isnaini et al., 2015; Khosravi et al., 2013; Martirosyan, 2015; Negricea et al., 2014; Weerasinghe \& Fernando, 2018a, 2018b).

The results of the study also showed that teaching quality of lecturers were able to mediate the relationship between GUG and learning facilities to student satisfaction. The type of mediation is partial mediation which means that GUG and learning facilities can affect student satisfaction directly and indirectly (through TQL). The effect of GUG and learning facilities will be stronger if through TQL. Good university governance will encourage the quality of teaching lecturers to be better and ultimately will affect student satisfaction. Good learning facilities will help lecturers in improving the quality of teaching and ultimately able to increase student satisfaction.

Learning facilities also proved to have a positive and significant effect on GUG. This means the quality and availability of learning facilities will also encourage the creation of good university governance. The GUG principle will be implemented properly if there are adequate facilities. Transparency and accountability will be created if universities have quality facilities. Higher education management will be able to provide the best service if they have adequate lecture facilities.

\section{Conclusion}

Good university governance (GUG) is the main predictor in influencing student satisfaction. GUG also has a positive and significant effect on the quality of teaching lecturers. The implementation of good university governance encourages the creation of transparency, accountability, independence, efficiency and justice. Student satisfaction will increase if institutions are managed by implementing the GUG principle. The implementation of GUG will also be influenced by the existence and quality of good and modern facilities.

Referring to the results of the research, higher education management should implement the GUG better. GUG will ensure the implementation of higher education programs more regularly in accordance with the vision and mission that has been set. Student satisfaction is one of the important indicators to measure the success or performance of 
college management. The better student satisfaction will encourage the continuity of higher education. There will be complaints or protests from students that will disturb the learning process. In addition, lecturers and staff will be able to work more calmly. Higher education management will be more trustworthy.

\section{Acknowledgements}

The authors would like to express gratitude to Faculty of Economics, Universitas Negeri Semarang for research and publication funding. We also thanks to Editor of International Journal of Higher Education for the publication.

\section{References}

Adams, J. S. \& Freedman, S. (1976). Journals \& Books Equity Theory Revisited: Comments and Annotated Bibliography, Advances in Experimental Social Psychology, 9, 43-90. https://doi.org/https://doi.org/10.1016/S0065-2601(08)60058-1 Get

Ali, F., Zhou, Y., Hussain, K., Nair, P. K. \& Ragavan, N. A. (2016). Does higher education service quality effect student satisfaction, image and loyalty? Quality Assurance in Education, 24(1), 70-94. https://doi.org/10.1108/qae-02-2014-0008

Almana, L. O., Sudarmanto \& Wekke, I. S. (2018). Tata Kelola Perguruan Tinggi Berbasis Akreditasi. Yogyakarta: Deepublish.

Annamdevula, S. \& Bellamkonda, R. S. (2016). Effect of student perceived service quality on student satisfaction, loyalty and motivation in Indian universities: Development of HiEduQual, Journal of Modelling in Management, 11(2), 488-517. https://doi.org/10.1108/JM2-01-2014-0010

Aprilia, L. (2017). Pengaruh Good University Governance terhadap Kepuasan Mahasiswa (Studi Kasus pada Mahasiswa FEBI UIN Walisongo Semarang). UIN Walisongo Semarang. Retrieved from http://eprints.walisongo.ac.id/7973/

Butt, B. Z. \& Rehman, K. U. (2010). A study examining the students satisfaction in higher education, Procedia Social and Behavioral Sciences, 2, 5446-5450. https://doi.org/10.1016/j.sbspro.2010.03.888

Carter, S. \& Yeo, A. C.-M. (2016). Students-as-customers' satisfaction, predictive retention with marketing implications: The case of Malaysian higher education business students, International Journal of Educational Management, 30(5), 635-652. https://doi.org/https://doi.org/10.1108/ IJEM-09-2014-0129

Fernandes, C., Ross, K. \& Meraj, M. (2013). Understanding student satisfaction and loyalty in the UAE HE sector, International Journal of Educational Management, 27(6), 613-630. https://doi.org/10.1108/IJEM-07-2012-0082

Freeman, R. E., Wicks, A. C. \& Parmar, B. (2004). Stakeholder Theory and "The Corporate Objective Revisited": A Reply, Organization Science, 15(3), 364-369. https://doi.org/10.1287/orsc.1040.0067

Ghozali, I. \& Chariri, A. (2007). Teori Akuntansi. Semarang: Badan Penerbit UNDIP.

Isnaini, M., Wardani, D. K. \& Noviani, L. (2015). Pengaruh Kompetensi Dosen dan Fasilitas Belajar Terhadap Kepuasan Mahasiswa Pendidikan Ekonomi FKIP UNS, Jurnal Pendidikan Bisnis Dan Ekonomi, 1(2), 1-20. Retrieved from https://jurnal.fkip.uns.ac.id/index.php/ptn/article/view/7353/5130

Jensen, M. C. \& Meckling, W. H. (1976). Theory of the Firm: Managerial Behavior, Agency Costs and Ownership $\begin{array}{llll}\text { Structure, Journal of } & \text { Financial }\end{array}$ https://doi.org/https://doi.org/10.1016/0304-405X(76)90026-X

Kardoyo \& Nurkhin, A. (2016). Analisis Kepuasan Pelayanan Perguruan Tinggi (Kasus pada Prodi Magister $\begin{array}{llll}\text { Pendidikan Ekonomi Unnes), Cakrawala Pendidikan, } & \text { XXXI(02), 164-175. }\end{array}$ https://doi.org/http://dx.doi.org/10.21831/cp.v15i2.9881

Khosravi, A. A., Poushaneh, K., Roozegar, A. \& Sohrabifard, N. (2013). Determination of Factors Affecting Student Satisfaction of Islamic Azad University, Procedia - Social and Behavioral Sciences, 84, 579-583. https://doi.org/10.1016/j.sbspro.2013.06.607

Kotler, P. \& Keller, K. L. (2008). Manajemen Pemasaran (Edisi ketiga belas). Jakarta: Erlangga.

Listyaningrum, D., Handoyo, S. S. \& Murtinugraha, R. E. (2016). Pengaruh Kinerja Mengajar Dosen terhadap Kepuasan Belajar Mahasiswa Program Studi Pendidikan Teknik Bangunan Fakultas Teknik UNJ, Jurnal Pendidikan Teknik Sipil, 5(2), 88-98. https://doi.org/https://doi.org/10.21009/jpensil.v5i2.7251

Martini, R., Sari, K. R. \& Wardhani, R. S. (2015). Analisis penerapan good university governance melalui efektivitas 
pengendalian intern dan komitmen organisasional. In Simposium Nasional Akuntansi XVIII (pp. 1-23). Medan: Universitas Sumatera Utara. Retrieved from http://elib.ibs.ac.id/materi/Prosiding/SNA XVIII/makalah/104.pdf

Martirosyan, N. (2015). An examination of factors contributing to student satisfaction in Armenian higher education, International Journal of Educational Management, 29(2), 177-191. https://doi.org/10.1108/IJEM-09-2013-0143

Motefakker, N. (2016). The Study of the Level of Satisfaction of the Students of the Faculty of Social Sciences with Welfare Services of Imam Khomeini International University of Qazvin, Procedia Economics and Finance, 36(16), 399-407. https://doi.org/10.1016/s2212-5671(16)30052-1

Muktiyanto, A. (2016). Good University Governance Dan Kinerja Perguruan Tinggi. In Institusi Pendidikan Tinggi di Era Digital: Pemikiran, Permodelan dan Praktek Baik (pp. 45-66). Retrieved from http://repository.ut.ac.id/7059/1/UTFEKON2016-03.pdf

Negricea, C. I., Edu, T. \& Avram, E. M. (2014). Establishing Influence of Specific Academic Quality on Student Satisfaction, Procedia - Social and Behavioral Sciences, 116, 4430-4435. https://doi.org/10.1016/j.sbspro.2014.01.961

Osman, A. R. \& Saputra, R. S. (2019). A pragmatic model of student satisfaction: a viewpoint of private higher education, Quality Assurance in Education, 27(2), 142-165. https://doi.org/10.1108/QAE-05-2017-0019

Poon, J. \& Brownlow, M. (2015). Real estate student satisfaction in Australia: What matters most? Property Management, 33(2), 100-132. https://doi.org/10.1108/PM-05-2014-0023

Putri, M. K. (2018). Pengaruh Kinerja Dosen dan Pelayanan Administratif terhadap Kepuasan Mahasiswa pada Sekolah Tinggi Ilmu Ekonomi Indragiri (STIE-I) Rengat Kabupaten Indragiri Hulu, Jurnal Manajemen Dan Bisnis, VII(04), 46-56. https://doi.org/https://doi.org/10.34006/jmb.v7i4.18

Rahmawati, D. (2013). Analisis Faktor-Faktor Yang Mempengaruhi Kepuasan Mahasiswa, Jurnal Economia, 9(1), 52-65. https://doi.org/10.1016/S0891-5245(03)00149-4

Sabihaini \& Satoto, S. H. (2016). Analisis Pengaruh Kompetensi Dosen dan Fasilitas Belajar Terhadap Tingkat Kepuasan Mahasiswa Program Studi Magister Manajemen Fakultas Ekonomi dan Bisnis UPN "Veteran" Yogyakarta, Journal of Economic \& Social, 2(1), 11-20. Retrieved from http://eprints.upnyk.ac.id/id/eprint/17490

Tajuddin, M., Nimran, U., Astuti, E. S. \& Kertahadi. (2016). Kesuksesan Sistem Informasi Perguruan Tinggi dan Good University Governance: sebuah kajian empiris di perguruan tinggi swasta. Malang: UB Press.

Tjiptono, F. (2002). Manajemen Jasa. Yogyakarta: ANDI.

Tjiptono, F. \& Chandra, G. (2015). Pelanggan Puas? Tidak Cukup! Yogyakarta: ANDI.

Wahab, A. A. \& Rahayu, S. (2013). Pengaruh Penerapan Prinsip-Prinsip Good University Governance Terhadap Citra Serta Implikasinya Pada Keunggulan Bersaing Perguruan Tinggi Negeri Pasca Perubahan Status Menjadi BHMN, Jurnal Administrasi Pendidikan, 17(1), 154-173. Retrieved from http://ejournal.upi.edu/index.php/JAPSPs/article/view/6441

Wahyudin, A., Nurkhin, A. \& Kiswanto. (2017). Hubungan good university governance terhadap kinerja manajemen keuangan perguruan tinggi, Jurnal Keuangan Dan Perbankan, 21(1), 60-69. Retrieved from http://jurnal.unmer.ac.id/index.php/jkdp/article/view/1227/812

Weerasinghe, I. M. S. \& Fernando, R. L. S. (2018a). Critical factors affecting students' satisfaction with higher education in Sri Lanka, Quality Assurance in Education, 26(1), 115-130. https://doi.org/10.1108/QAE-04-2017-0014

Weerasinghe, I. M. S. \& Fernando, R. L. S. (2018b). University facilities and student satisfaction in Sri Lanka, International Journal of Educational Management, 32(5), 866-880. https://doi.org/10.1108/IJEM-07-2017-0174

Xiao, J. \& Wilkins, S. (2015). The effects of lecturer commitment on student perceptions of teaching quality and student satisfaction in Chinese higher education, Journal of Higher Education Policy and Management, 37(1). https://doi.org/https://doi.org/10.1080/1360080X.2014.992092 